\title{
BRITISH LIBRARY WORKING PARTY ON PROVISION FOR LAW
}

The British Library has recently set up a working party to advise on the future development of its services in the area of law, to the legal profession, academics, and the wider public. The working party is currently seeking opinion and comment from users of legal literature and legal information services, based on their experience of libraries and upon their own needs.

The working party would be particularly grateful for comment on the following group of closely-related questions:

- in the provision of legal literature in libraries over the country as a whole, what gaps or inadequacies are there?

- what particular difficulties are there in finding UK legislative material? for example, local legislation, and legal literature from smaller jurisdictions?

- what areas of overseas law are not covered by UK libraries, or are difficult of access?

- what kind of service is needed from the national library to support the direct library services available to most users?

- to what extent are loan, photocopy and telephone enquiry services likely to satisfy the needs of users not able to visit the British Library Reference Division in London?

- what are the implications of the new technology for library provision in the legal field?

The terms of reference mention the following as likely to be fruitful areas of discussion.

1. The organisation of the British Library's collections in such a way as to make them as widely available and accessible as possible, bearing in mind the accommodation and other constraints on the British Library and in the context of the British Library's total range of services.

2. Developing the reference service in relation to these collections.

3. Acquisition of additional material, especially if not at present available in the UK. 
4. The best use of bibliographical and other records in maintaining and improving library and information services in the legal field.

5. New forms and channels of regular communication between the $\mathrm{BL}$ on the one hand and law libraries and users of legal literature and information on the other.

Comments, enquiries and submissions will be welcomed by the Secretary, Miss Mary Goldrick, The British Library, Official Publications Library, Great Russell Street, London WC1B 3DG (Telephone 01-6361544 ext. 234). These should be sent by March 1982 at the latest.

\section{FELLOWSHIPS FOR FOREIGN LAW LIBRARIANS IN THE UNITED STATES}

The Charles A. Dana Foundation in the United States, which made a generous grant to the IALL in 1978 for the purpose of holding its highly successful first Latin American Conference in Quito, Ecuador, has further extended its support for the advancement of international law librarianship through the creation of a Fellowship for Foreign Law Librarians.

The first recipients of the Fellowship in 1981 were Ms. Vivian Fletcher, Assistant Librarian at the Law Library of King's College, the University of London, and Ms. Rasri Thepuichien, the librarian for the International Legal Counsellors Thailand Ltd. in Bangkok, Thailand.

Each participant spent this summer studying law library operations in Southern California where their sponsors were the California Western School of Law Library, the San Diego County Law Library, and the Library of the California State Attorney General.

\section{CENTRAL AMERICAN COMMON MARKET BIBLIOGRAPHY}

Ellen Schaffer, Reference Librarian at the Columbus Memorial Library of the Organization of American States in Washington, has compiled an interesting 10-page bibliography of books and articles on the Central American Common Market covering the period from 1975 through 1980. The bibliography has been issued by the OAS General Secretariat as item No. 4 in its Documentation and Information Series (Document No. OEA/SG/0.1/IV/III.4).

The Central American Common Market came into existence in 1960 pursuant to the Central American Integration Treaty. That treaty expired in June, 1981, and there are plans in existence for negotiations leading to the establishment of a new regional economic arrangement in 